\title{
Pengambilan Data Pasien Stroke Menggunakan Sinyal EEG Sebagai Informasi Pengambilan Keputusan Melakukan Tindak Lanjut Rehabilitasi
}

\author{
MY Teguh Sulistyono \\ Universitas Dian Nuswantoro \\ e-mail: teguh.sulistyono@dsn.dinus.ac.id
}

Diterima: 19 Februari 2021; Direvisi: 24 April 2021; Disetujui: 06 Mei 2021

\begin{abstract}
Abstrak
Stoke merupakan penyakit tidak menular, merupakan jenis penyakit kardiovaskuler yang disebabkan oleh gangguan pembuluh darah dengan urutan ke dua penyebab kematian di dunia sebanyak $45 \%$ penduduk dunia meninggal akhibat stroke setiap tahunnya dan di Indonesia sekitar 7\%. Stroke dapat juga menyebabkan cacat permanen, depresi, demensia dan stress jika tidak ditangani dengan benar karena ketidaktahuan dalam penanganannya. Yang menjadi masalah dalam penanganan stroke adalah pasca terkena stroke yang melakukan rehabilitasi medis untuk mengembalikan fungsi motorik pasien. Dalam prakteknya tenaga medis sulit melakukan penilaian pengukuran yang akurat terhadap proses rehabilitasi pasien pasca terkena stroke. Hal ini terjadi karena tenaga medis masih menggunakan pencatatan progres secara konfensional. Metode yang digunakan dalam melakukan penelitian pengambilan data pasien pasca terkena stroke menggunakan sinyal EEG sebagai informasi pengambilan keputusan dalam melakukan tindakan lanjut dalam rehabilitasi medis menggunakan tahapan yaitu Persiapan, Studi Literature, Pemilihan Partisipan, Eksplorasi Alat, Pemilihan Gerakan, Pengambilan Data. Hasil akhir yang didapat sebagai output dalam penelitian ini adalah berupa data yang telah terekan dalam bentuk raw data dengan 46.080 data frame yang diolah dengan metode ANOVA menghasilkan nilai rata-rata sebesar $96 \%$ dan memiliki nilai $F<5.143253$, sehingga hasil hipotesanya dapat diterima dan dilanjutkan proses serikutnya sebagai media dalam penentuan penanganan rehabilitasi medis pasien stroke.
\end{abstract}

Kata kunci: Stroke, Rehabilitasi Medis, EEG, Pengukuran, Penilaian

\begin{abstract}
Stoke is a non-communicable disease, is a type of cardiovascular disease caused by blood vessel disorders with the second leading cause of death in the world as much as $45 \%$ of the world's population dies due to stroke every year and in Indonesia around 7\%. Stroke can also cause permanent disability, depression, dementia and stress if not handled properly due to ignorance in handling it. The problem in stroke management is that after a stroke, medical rehabilitation is carried out to restore the patient's motor function. In practice, medical personnel find it difficult to make accurate measurement assessments of the post-stroke patient rehabilitation process. This happens because medical personnel are still using conventional progress recording. The method used in conducting research data retrieval of post-stroke patients uses EEG signals as information for decision making in taking further action in medical rehabilitation using stages, namely preparation, literature study, participant selection, tool exploration, movement selection, data collection. The final result obtained as output in this study is in the form of data that has been encoded in the form of raw data with 46,080 data frames processed by the ANOVA method resulting in an average value of $96 \%$ and has a value
\end{abstract}


of $F<5.143253$, so that the results of the hypothesis can be accepted and continued. the following process as a medium in determining the treatment of stroke patient medical rehabilitation.

Keywords: Stroke, Medical Rehabilitation, EEG, Measurement, Assessment

\section{PENDAHULUAN}

Stroke merupakan penyakit yang menyebabkan kematian ke dua didunia dan penyebab cacad baik permanen atau semi permanen ke tiga didunia. Menurut Word Health Organization (WHO), stroke merupakan penyakit yang disebabkan serangan dimana berupa tanda klinis yang ditemukan berkembang secara cepat berupa deficit neorologik focal dan global, yang serangannya berlangsung kurang lebih 24 jam tanpa ada penyebab lain selain vaskuler yang dapat memberatkan orang yang terkena stroke serta dapat menyebabkan kematian seketika. Jika tidak ditangani baik itu stroke ringan atau berat dapat menyebabkan penderita mengalami demensia, depresi dan stress serta dapat menyebabkan disabilitas bagi penderita bahkan dapat merenggut nyawa penderita [1].

Menurut Pusat Data Informasi Kementrian Kesehatan RI pada tahun 2013 di dunia sebanyak $45 \%$ penduduk dunia meninggal diakhibatkan oleh penyakit stroke, begitu juga di Indonesia, pada tahun 2013 berdasarkan diagnosis tenaga kesehatan (Nakes) mengenai penyakit stoke diperkirakan sebanyak 1.236 .825 orang $(7,0 \%)$, sedangkan berdasarkan diagnosis Nakes/gejala diperkirakan sebanyak 2.137 .941 orang $(12,1 \%$ ), dan diperkirakan akan terus bertambah 23,3 juta kematian di dunia hingga tahun 2030 [2].

Dalam penanganan masalah tersebut diatas bagi orang-orang yang saat ini masih sehat langkah yang harus dihadapi agar tidak terkena stroke adalah menjaga pola hidup sehat, mengatur pola makan yang tidak berkolesterol dan rutin berolahraga. Harus diwaspadai tandatanda pada pasien terkena stroke senyum tidak simetris, sebagian

Tubuh lemah separuh, bicara pelo, separuh badan kesemutan, fungsi keseimbangan tidak stabil, dan pandangan salah satu mata kabur secara tiba-tiba. Jika menemui gejala tersebut diatas dan untuk meminimalisir tingkat keparahan harus segera diperiksakan dan ditangani secepatnya serta sesegera mungkin melalui tenaga medis dalam jangka waktu 3 sampai 4 jam untuk menghindari kecacatan permanen bahkan meninggal dunia.

Selain masalah tersebut diatas terdapat juga masalah-masalah lain dalam penanganan khususnya pada pasien pasca terkena stroke yang salah satunya adalah proses rehabilitasi medis. Rehabilitasi medis adalah proses pembenahan secara fisik, psikologis dan sosial pasien untuk lebih dimaksimalkan agar pulih seperti sedia kala [3]. Proses rehabilitasi medis melibatkan tenaga medis dalam memonitoring perkembangan selama melakukan proses rehabilitasi medis. Dalap proses rehabilitasi medis, tenaga medis sulit melakukan penilaian pengukuran yang akurat terhadap progress proses rehabilitasi pasien pasca terkena stroke. Hal ini terjadi karena tenaga medis dalam melakukan proses rehabilitasi masih menggunakan metode konfensional [4].

Untuk menangani masalah diatas maka diperlukan suatu metode pengambilan data dengan menggunakan sinyal EEG untuk penanganan aktivitas gelombang otak selama proses rehabilitasi berlangsung. Selama proses rehabilitasi data sinyal gelombang otak tersebut akan dilakukan monitoring, sehingga hasil dari monitoring data tersebut dapat digunakan sebagai informasi awal dalam melakukan tindakan lanjut yang akan diambil dalam pemulihan pasien pasca terkena stroke.

\section{METODE PENELITIAN}

Metode yang digunakan untuk mencapai tujuan penelitian adalah melakukan penelitian pengambilan data pasien pasca terkena stroke menggunakan sinyal electroencephalograph 
(EEG) sebagai informasi pengambilan keputusan dalam melakukan tindakan lanjut dalam rehabilitasi. Gambaran umum metode penelitian terdiri dari 6 (enam) tahap (gambar 1) yang terdiri dari Persiapan, Studi Literature, Pemilihan Partisipan, Eksplorasi Alat, Pemilihan Gerakan, Pengambilan Data.

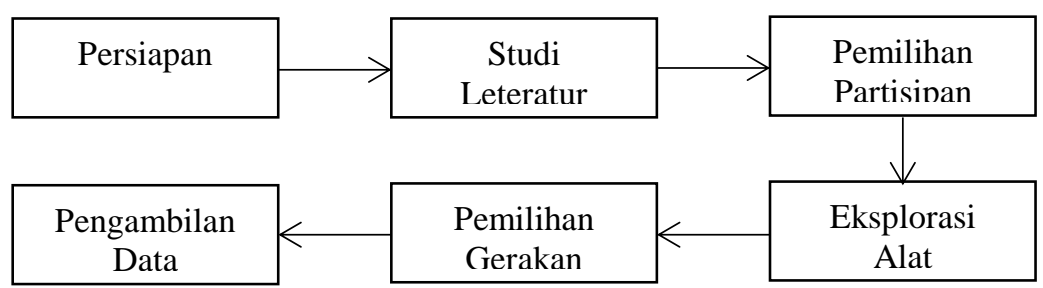

Gambar 1. Gambaran Umum Metode Penelitian

\subsection{Persiapan}

Tahap persiapan merupakan tahap awal dari penelitian ini, dimana peneliti harus memastikan semua tahapan-tahapan yang akan dilakukan berjalan dengan lancar, dan memastikan partisipan sudah tersedia, alat sudah siap digunakan, gerakan dan waktu gerakan sudah disusun sesuai dengan rencana. Hal ini disebabkan karena pada saat pengambilan data dilakukan secara terintegrasi antara semua tahap, sehingga pada tahap ini harus dipastikan semua sudah siap untuk melakukan kegiatan pengambilan data.

\subsection{Studi Literatur}

Dalam penelitian ini sesuai dengan tujuan dari penelitian, penulis mencari referensireferensi yang berkaitan dengan EEG Beberapa literatur yang berhasil penulis dapatkan yang berhasil dikumpulkan berkisar pada EEG motor task dan EEG motor movement yang bertujuan untuk memantau pergerakan aktivitas tugas motorik di otak dan memantau pergerakan aktivitas motorik di otak. Kedua materi tersebut semua berhubungan dengan Frontal Lobe, dimana sinyal yang didapat dari elektroda frontal lobe dapat digunakan untuk pendeteksi motor task dan motor movement melalui sinya EEG dan dapat juga penempatannya pada elektroda di titik C3 dan $\mathrm{C} 4$ [5].

\subsection{Pemilihan Partisipan}

Partisipan adalah pasien yang pasca terkena stroke untuk mengetahui pola sinyal EEG sisi yang terkena stroke dan sisi yang sehat. Pemilihan partisipan sangatlah penting dan dapat dipertanggungjawabkan jika memilih partisipan yang tepat dengan menggunakan dasar bahwa penelitian yang melibatkan manusia harus menggunakan uji kelayakan etik (ethical clearance) untuk menjaga agar proses penelitian mengikuti prinsip umum etika penelitian tentang kesehatan. Untuk itu data patisipan yang didapat bekerasama dengan Rumah Sakit Umum Universitas Airlangga (RSUA) dalam pengambilan data agar mendapat kelayakan etik dari Komite Etik RSUA [6].

Dalam pemilihan partisipan untuk diambil data sinyal EEG harus memiliki ketentuan yang telah ditetapkan yaitu sebagai berikut:

a. Partisipan merupakan pasien RSUA yang memiliki penyakit stroke dan sedang menjalini proses rehabilitasi.

b. Partisipan tidak dibatasi umur.

c. Partisipan dalam kondisi sehat jasmani dan rohani serta tidak ada tekanan untuk perekaman data mengunakan alat EEG.

d. Partisipan mampu berkomunikasi dan bersedia melakukan perintah-perintah yang akan diterapkan selama pengambilan data. 
e. Partisipan tidak ada umsur paksaan dalam perekaman data menggunakan alat EEG.

Sebelum melakukan pengambilan data peneliti bekerjasama dengan petugas medis dan pasien untuk mengatur waktu yang tepat untuk pengambilan data.

\subsection{Eksplorasi Alat}

Dalam penelitian ini penulis menggunakan alat Headset UltraCortex "Mark IV" dengan motherboard openBCI Cython yang merupakan produk dari OpenBCI (Open Source BrainComputer Interface) (gambar 2). Alat ini memiliki sifat portable dan memiliki akurasi yang baik terhadap pembacaan sinyal EEG dan alat ini dipergunakan untuk merekam aktivitas otak yang berada diposisi area motor cortex [7].Alat ini terdiri dari 2 yaitu :

a. Ultracortex Mark IV Headset

Ultracortex Mark IV Headset terdiri dari 16-35 channel yang compatible dengan semua OpenBCI Board dan penempatan elektroda pada headset mengacu pada aturan Internasional yaitu 10-20.
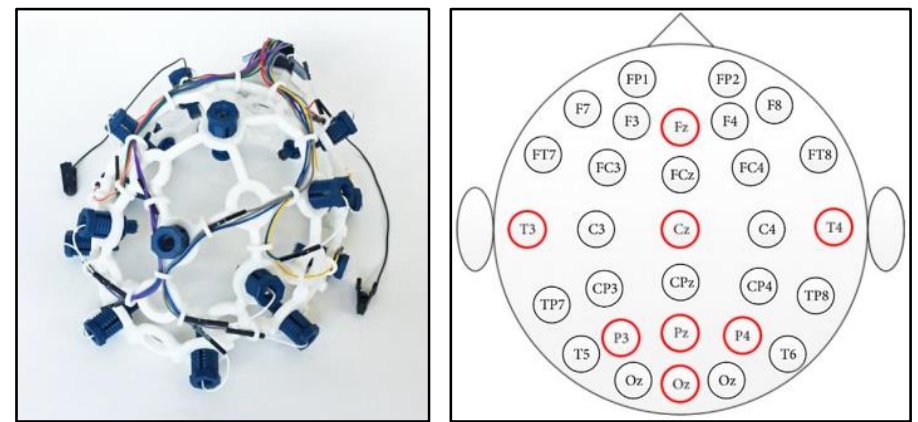

Gambar 2. Ultracortex Mark IV Headset Dan Internasional 10-20 Channel

\section{b. OpenBCI Cyton Board}

OpenBCI Cyton Board terdiri dari 8 chnnel dengan memiliki processor 32 bit yang mampu memberikan banyak memori local dan kecepatan pemrosesan yang baik tampak pada gambar 3. Selain digunakan untuk merekam aktivitas otak, alat ini juga dapat merekam aktivitas otot (EMG) dan merekam aktivitas jantung (ECG)

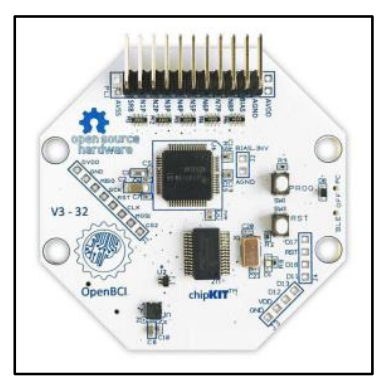

Gambar 3. OpenBCI Cyton Board
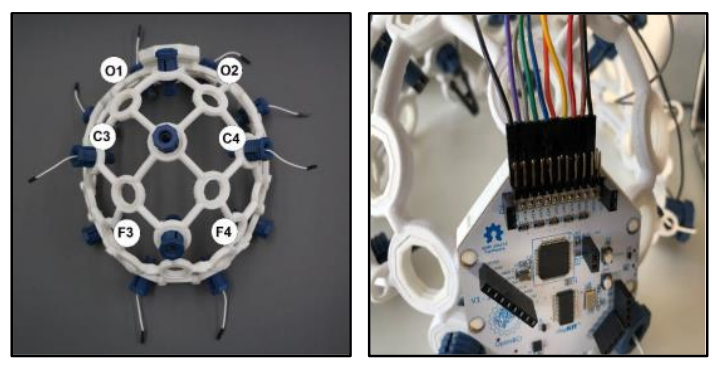

Gambar 4. Penggabungan Antara Ultracortex Mark IV Headset dan OpenBCI Cyton Board 
Pada gambar 4 menujukan Ultracortex Mark IV Headset dan OpenBCI Cyton Board harus disatukan menjadi satu kesatuan agar dapat dipergunakan untuk merekam aktivitas otak. Pemanfaatan elektroda disesuaikan dengan kebutuhan penelitian, dalam penelitian ini penulis menggunakan 6 channel yang letaknya pada frontal, cortex dan occipital yang ditandai dengan channel $\mathrm{F} 3, \mathrm{~F} 4, \mathrm{C} 3, \mathrm{C} 4, \mathrm{O} 1$ dan $\mathrm{O} 2$.

\subsection{Pemilihan Gerakan}

Pemilihan gerakan dalam penelitian ini menggunakan metode gerakan berdasar Manual Muscle Testing (MTM) yang merupan metode pengukuran kekuatan otot berdasar referensi dari fisioterapis. Gerakan dalam MMT mudah karena sudah popular dan sering diperagakan dalam dunia olahraga seperti senam.

Gerakan-gerakan yang dipilih dalam perekaman aktivitas otak yang mengacu pada metode MMT dipilih sesuai dengan kondisi pasien, dalam hal ini sesuai dengan penelitian yang dibahas memiliki 3 kriteria gerakan yaitu :
a. Flexi - Ekstensi Siku
b. Flexi-Ekstensi Bahu
c. Flexi-Ekstensi Genggam

(a)

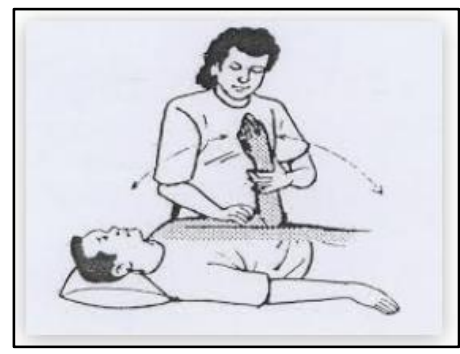

(a)

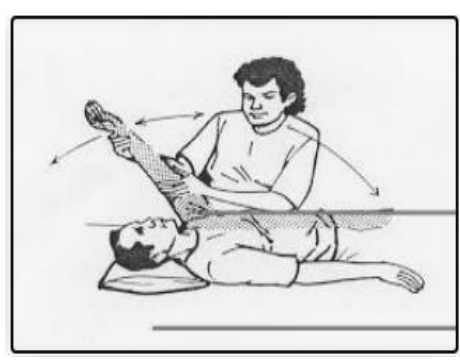

(b)

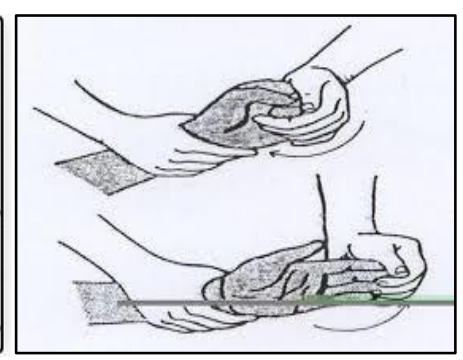

(c)

Gambar 5. Gerakan Uji Pada Pasien Pasca Terkena Stroke

\subsection{Pengambilan Data}

Pengambilan data dilakukan dengan melakukan perekaman aktivitas otak dengan meletakkan alat pada kepala pasien, hardware dan software disiapkan untuk memulai proses perekaman aktivitas otak.

Pengambilan data dilakukan dengan menggunakan 2 metode yaitu :a) Persiapan Perekaman, b) Perekaman Data

Pengambilan data aktivitas otak pasien diminta untuk melakukan gerakan yang sudah dipersiapkan sesuai dengan arahan telah disepakati oleh pasien dan pengambil data. Data aktivitas otak yang didapat akan menjadi informasi awal untuk mengolah data pada tahap berikutnya untuk mengetahui informasi lanjut terhadap proses rehabilitasi yang sedang berlangsung. Dengan melakukan monitoring terus menerus terhadap pengambilan data maka akan diketahui tindak lanjut yang akan diambil untuk proses rehabilitasi selanjutnya.

\section{HASIL DAN PEMBAHASAN}

Penelitian pengambilan data pasien pasca terkena stroke menggunakan sinyal EEG sebagai informasi pengambilan keputusan melakukan tindak lanjut rehabilitasi menghasilkan informasi yang terbagi menjadi 2 tahapan. Dimana urutan prosedur tampak dalam gambar 6 . 


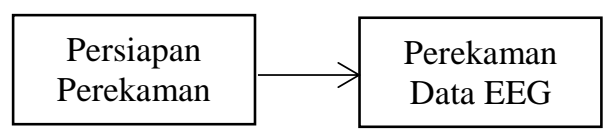

Gambar 6. Prosedur Pengambilan Data

\subsection{Persiapan Perekaman}

Persiapan perekaman aktifitas otak dilakukan dengan menggunakan tahapan-tahapan sebagai berikut :

a. Penjelan Prosedur Penelitian

Sebelum pengambilan atau perekaman data aktivitas otak, pasien diberi penjelasan mengenai tujuan dari penelitian dan hal-hal yang berkait dengan penelitian. Pasien juga akan diberitahu mengenai hak-hak pasien selama penelitian berlangsung. Mengapa perlu diberi penjelasan karena selama masa pengambilan data aktivitas otak dibutuhkan prosedurprosedur yang harus dilalui oleh pasien dan peneliti agar dalam proses pengambilan data berjalan dengan lancar. Hal ini dikarenakan pasien pasca terkena stroke lebih cenderung menutup diri dan kurang mengetahui manfaat yang didapat setelah pengambilan data tersebut berlangsung.

b. Pengisian inform consent

Inform consent merupakan suatu formulir yang berisi ketersediaan pasien untuk melakukan uji perekaman aktivitas otak. Inform consent juga berisi tentan prosedur gambaran singkat penelitian yang disampaikan kepada pasien selama mengikuti test pengambilan data. Dengan adanya Inform consent pasien tidak merasa dipaksa oleh pihak lain dan sukarela untuk mengikuti test dengan harapan dapat menyumbang data demi majunya sebuah penelitian.

c. Menyiapkan Posisi Badan Pasien

Setelah selesai menyetujui Inform consent, maka pasien disuruh menempatkan pada posisi duduk untuk melakukan serangkaian test. Selama dalam posisi duduk pasien dianjurkan berada dalam keadaan tenang atau rileks agar data yang nanti diambil tidak banyak terjadi noise baik dari jala-jala listrik yang diakhibatkan oleh alat dan noise yang disebabkan oleh gerakan pasien sendiri seperti kejang, tegang atau kedipan mata.

d. Latihan Gerakan Yang Akan Diuji

Setelah pasien duduk dalam keadaan rileks, pasien dilatih dahulu gerakan-gerakan yang nanti akan diambil pada saat perekaman sinyal EEG. Gerakan-gerakan tersebut sesuai dengan penelitian menggunakan 3 macam gerakan yaitu mengangkat siku, mengangkat bahu dan menggenggam baik tangan kiri maupun tangan kanan, dimana dalam 3 gerakan tersebut masing-masing gerakan diberi waktu istirahat kemudian melakukan gerakan selanjutnya.

\subsection{Perekaman Data EEG}
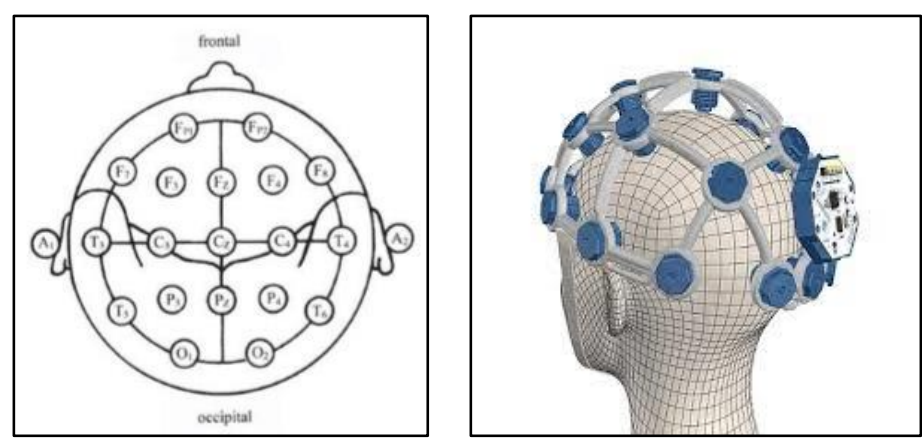

Gambar 7. Peletakkan Elektroda Dan Pemasangan Alat 
Perekaman data EEG dilakukan dengan menggunakan tahapan-tahapan sebagai berikut:

a. Pemasangan Alat

Pemasangan alat tampak pada gambar 7 diletakkan pada kepala partisipan dengan elektroda diletakkan pada channel F1, F2, C3, C4, O1, dan O2 sedangankan A1 dan A2 diletakkan sebagai refrensi.

Pemasangan elektroda sesuai dengan urutan warna kabel seperti pada tabel 1 berikut:

Tabel 1 Peletakan Elektroda

\begin{tabular}{lll}
\hline Electrode & Wire Color & Cyton Board Pin \\
\hline Ear Clip & Black & Bottom SRB pin (SRB2) \\
F3 & Purple & Bottom N1P pin \\
F4 & Grey & Bottom N2P pin \\
C3 & Green & Bottom N3P pin \\
C4 & Blue & Bottom N4P pin \\
O1 & Red & Bottom N7P pin \\
O2 & Brown & Bottom N8P pin \\
Ear Clip & Black & Bottom BIAS pin \\
\hline
\end{tabular}

Setelah terpasang alat di kepala cyton board dinyalakan dan dihubungkan dengan komputer dengan interface yang ditunjukan pada gambar 8 melalui bluetooth dongle yang tersedia.

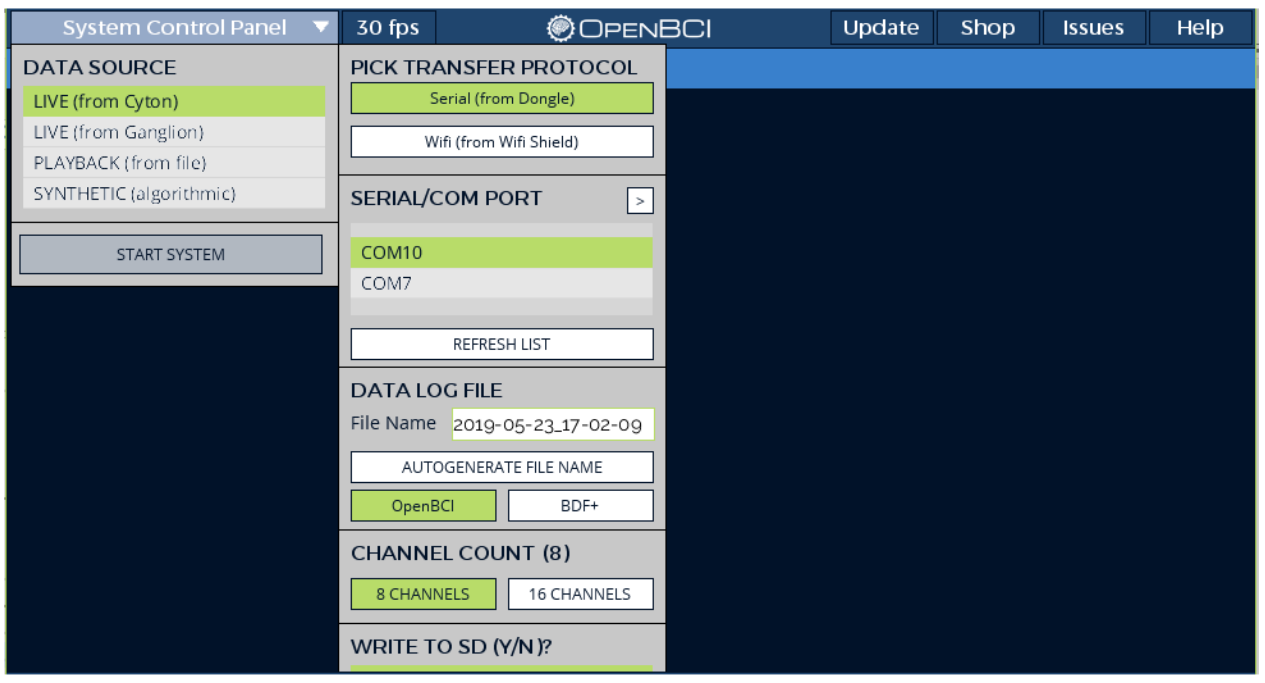

Gambar 8. Interface Software OpenBCI

b. Melakukan Sejumlah Gerakan

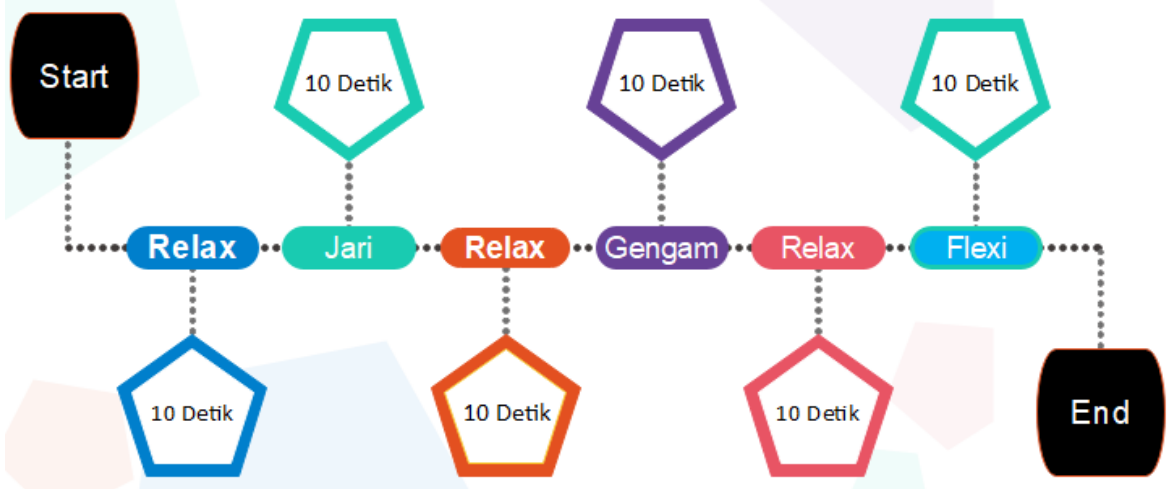

Gambar 9. Contoh Gerakan Untuk Jari 
Setelah partisipan dipasang alat dan sudah terkoneksi dengan interace di komputer, pastisipan melakukan beberapa gerakan yang mengacu pada gerakan MMT yaitu naik turun siku, naik turun bahu dan buka tutup genggaman yang berlangsung selama 60 detik sesuai instruksi seperti instruksi pada gambar 9 .

\section{c. Aktivitas Perekaman Otak}

Electroencephalogram (EEG) adalah instrumen yang digunakan untuk mengukur, merekam, memonitor aktifitas elektrik di sepanjang kulit kepala melalui penempatan elektroda dikepala. Ketika otak melakukan suatu aktivitas maka menghasilkan suatu gelombang atau sinyal elektrik. Gelombang yang dihasilkan memiliki informasi penting. Gelombang otak memiliki jenis yang memiliki informasi yang berbeda. Berdasarkan rentang frekuensi, sinyal otak utama terdiri dari alpha, theta, beta, delta, dan gamma [8].

Berdasarkan informasi diatas untuk melakukan perekaman data dibutuhkan alat (gambar 10), software dan gerakan disatukan dalam suatu proses maka semua aktiitas otak terekam dalam aplikasi OpenBCI.

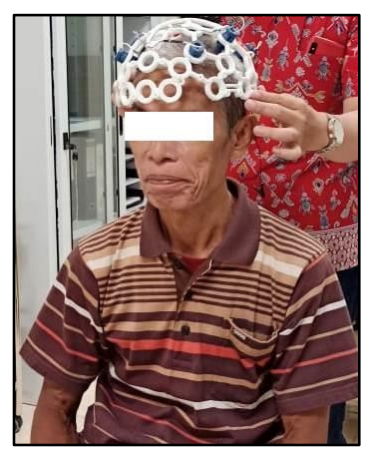

Gambar 10. Aktivitas Perekaman Sinyal EEG

Selama proses perekaman data-data partisipan yang melakukan test hasil output dari proses ini adalah data raw EEG (*.txt) dengan sample rate $256 \mathrm{~Hz}$.

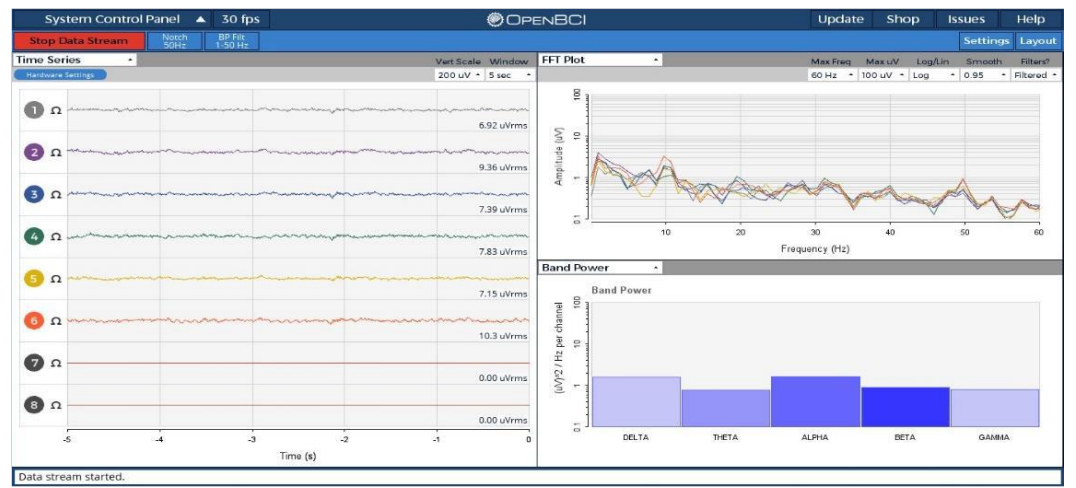

Gambar 11 Hasil Perekaman Sinyal EEG

Pada gambar 11 data pasien stroke direkam menggunakan tool OpenBCI yang hasil perekaman tersebut menghasilkan sinyal, amplitudo dan band power. Setelah direkam data tersebut menghasilkan data dalam bentuk data raw dapat dilihat pada sempel data yang ditunjukkan pada gambar 12: 


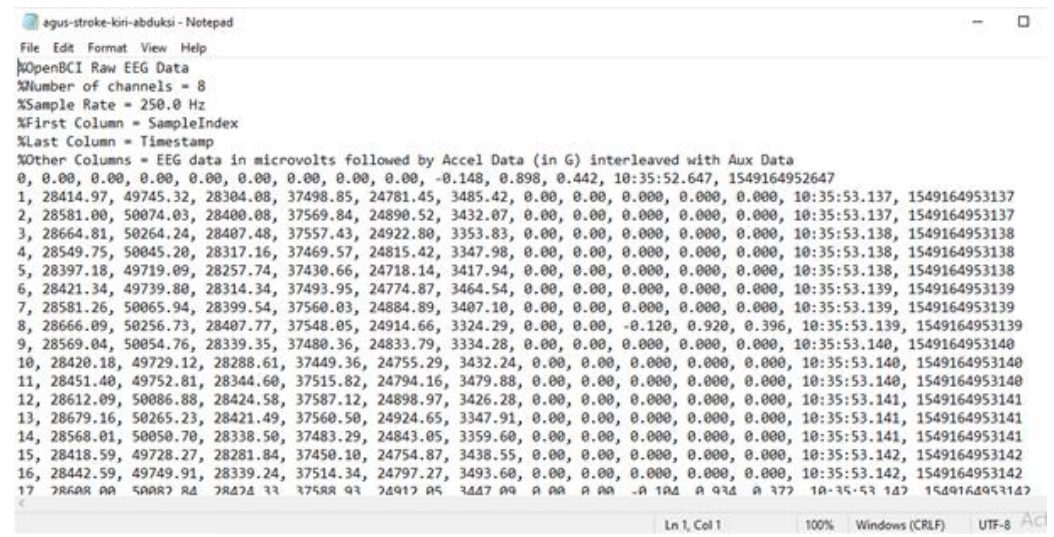

Gambar 12 Sempel Data Raw Yang Telah Direkam

Pada gambar 12 merupakan data raw hasil perekaman dengan tool OpenBCI yang didalamnya terdapat berapa channel yang digunakan, berapa sample rate, dan hasil dari perekaman sinyal yang tersusun dalam kolom-kolom.

\section{d. Hasil Uji Analisys Of Variance}

Analisis statistik yang menguji perbedaan rerata antar grup. Tujuan analisis statistik sebagai alat untuk menguji hipotesis penelitian perbedaan rerata antara kelompok [9]. Hasil akhir dari Analisys Of Variance adalah nilai $\mathrm{F}$ test atau $\mathrm{F}$ hitung. Nilai $\mathrm{F}$ hitung akan dibandingkan dengan nilai pada tabel F. Jika nilai $\mathrm{F}$ hitung lebih dari $\mathrm{F}$ tabel, maka dapat disimpulkan bahwa menerima $\mathrm{H} 1$ dan menolak $\mathrm{H} 0$ atau ada perbedaan bermakna rerata pada semua kelompok [10].

$$
y_{i . j}=\mu_{i+\varepsilon_{i . j}}
$$

Hasil dari Proses Analisy Of Variance ditampilkan pada tabel 2 dibawah ini :

Tabel 2 Hasil Analisys Of Variance

\begin{tabular}{llrrrrr}
\hline & & $\begin{array}{c}\text { Sum of } \\
\text { Squares }\end{array}$ & df & $\begin{array}{c}\text { Mean } \\
\text { Square }\end{array}$ & \multicolumn{1}{c}{ F } & \multicolumn{1}{c}{ Sig. } \\
\hline Sub Band 1 & Between Groups & .897 & 2 & .449 & 5.028 & .044 \\
& Within Groups & .625 & 7 & .089 & & \\
& Total & 1.522 & 9 & & & \\
Sub Band 2 & Between Groups & .586 & 2 & .293 & 2.351 & .166 \\
& Within Groups & .873 & 7 & .125 & & \\
& Total & 1.458 & 9 & & & \\
Sub Band 3 & Between Groups & .052 & 2 & .026 & .092 & .913 \\
& Within Groups & 1.972 & 7 & .282 & & \\
& Total & 2.023 & 9 & & & \\
Sub Band 4 & Between Groups & .048 & 2 & .024 & .142 & .870 \\
& Within Groups & 1.195 & 7 & .171 & & \\
& Total & 1.244 & 9 & & & \\
\hline
\end{tabular}

Tabel 2 menerangkan bahwa masing-masing kelompok sub band memiliki nilai rata-rata untuk nilai $\mathrm{F}$ hitung lebih kecil dari $\mathrm{F}$ tabel, dimana $\mathrm{F}$ tabelnya adalah 5.143253 atau $\mathrm{F}<5.143253$ dan untuk nilai rata-rata dari ke 4 sub band terdapat salah satu yang signifikan dengan p-nilai $<0.05$ yaitu sebesar $96 \%$, sehingga untuk uji hipotesa diterima dan dilanjutkan pada tahap berikutnya yaitu prosesesan data raw yang terdiri dari filter band, pembersihan nois, ekstrasi fitur, segmentasi dan dekomposisi sinyal EEG. 


\section{KESIMPULAN}

Pengambilan data dari sinyal EEG melalui aktivitas gelombang otak terhadap pasien yang terkena stroke dibutuhkan persiapan-persiapan yang harus diikuti dengan benar karena pada saat pengambilan data tersebut berhubungan keterlibatan manusia sebagai obyek penelitian sehingga harus dilakukan dengan benar. Untuk peneliti dalam pengambilan data menyertakan uji kelayakan etik (ethical clearance) untuk menjaga agar proses penelitian mengikuti prinsip umum etika penelitian tentang kesehatan. Alat untuk perekaman data aktivitas otak dapat menggunakan alat perekam aktivitas otak yang telah direkomendasikan oleh tenaga kesehatan melalui uji kelayakan dibid menggunakan uji kelayakan etik (ethical clearance) untuk menjaga agar proses penelitian mengikuti prinsip umum etika penelitian tentang kesehatan. ang kesehatan. Alat perekam aktivitas otak tersebut berfungsi merekan aktivitas otak yang ditempel diatas kulit kepala, EEG adalah alat yang mampu merekam aktivitas elektrik di sepanjang kulit kepala. EEG digunakan untuk mengukur fluktuasi tegangan yang didapat dari arus ion dalam neuron otak sehingga semua aktivitas otak dapat terekam dengan sempurna.

Pemilihan gerakan bertujuan untuk mengukur secara medis akibat dampak dari stroke untuk memunculkan spastisitas akibat dari upperlimb. Pemilihan gerakan dilakukan sesuai dengan rekomendasi dari terapis dan dari literature-literatur dalam bentuk metode seperti proprioceptive neuromuscular facilitation, neuro developmental treatment, sensory motor integration dan lain sebagainya, yang sebenarnyasemua gerakan tersebut membantu pasien dalam memulihkan fungsi motorik melalui latihan-latihan supaya menjadi normal kembali. Perekaman data sinyal EEG digunakan untuk melakukan record aktivitas otak dari pasien pasca terkena stoke menggunakan alat yang sudah direkomendasikan dan software yang telah terinstal serta menggunakan gerakan yang sudah ditetapkan, maka dengan adanya gabungan alat, software, dan gerakan perekaman aktivitas gelombang otak dapat dilakukan. Perekaman dilakukan untuk mengetahui perubahan pola sinyal EEG dari waktu ke waktu secara periodik. Diharapkan hasil yang diperoleh dapat digunakan sebagai dasar monitoring rehabilitasi stroke menggunakan EEG.

\section{DAFTAR PUSTAKA}

[1] Kemenkes RI, "Stroke Dont Be The One." Pusat Data Informasi Kementrian Kesehatan RI, Jakarta Indonesia, p. 10, 2018.

[2] K. K. RI, Pusat Data Dan Informasi Kementerian Kesehatan Republik Indonesia. Jakarta, Indonesia, 2014.

[3] W. K. Hass, “A journal of cerebral circulation,” Stroke, vol. 8, no. 3, pp. 299-301, 1977.

[4] S.-C. Park, J.-N. Ryu, J.-M. Park, B.-D. Seo, I.-T. Ryu, and Y.-J. Cha, "Effects of Cross Training with Bilateral Ankle Dorsiflexor Strengthening Exercise on the Muscle Activity of the Paralytic Tibialis Anterior, Balancing Ability, and Gait Function in Patients with Chronic Stroke: A Preliminary Randomized, Controlled Study," J. Korean Soc. Phys. Med., vol. 14, no. 4, pp. 63-70, 2019.

[5] H. Shibasaki et al., "Both primary motor cortex and supplementary motor area play an important role in complex finger movement," Brain, vol. 116, no. 6, pp. 1387-1398, 1993.

[6] H. Setiawan, W. R. Islamiyah, A. D. Wibawa, and M. H. Purnomo, "Identifying EEG Parameters to Monitor Stroke Rehabilitation using Individual Analysis," Proc. - 2019 Int. Semin. Intell. Technol. Its Appl. ISITIA 2019, pp. 337-342, 2019.

[7] J. Frey, "Comparison of an open-hardware electroencephalography amplifier with medical grade device in brain-computer interface applications," PhyCS 2016 - Proc. 3rd Int. Conf. Physiol. Comput. Syst., no. August, pp. 105-114, 2016.

[8] M. Teplan, "Fundamentals of EEG measurement," Meas. Sci. Rev., vol. 2, no. 2, pp. 1$11,2002$. 
[9] I. Ismawati, F. Oenzil, Y. Yanwirasti, and E. Yerizel, "Analisis Konsentrasi Low Density Lipoprotein Teroksidasi Serum pada Tahapan Aterosklerosis," J. Kedokt. Brawijaya, vol. 29, no. 4, pp. 348-352, 2017.

[10] D. Muriyatmoko, "Pengaruh Indeksasi Doaj Terhadap Sitasi Pada Jurnal Terakreditasi Sinta Menggunakan Analisis Regresi Linier," J. Simantec, vol. 7, no. 1, pp. 31-38, 2020. 